\title{
Israel: Is COVID-19 Expected More Than a War? (The Increase in Customs Value in Israel, Due to the COVID-19 Increase in Transport Prices - The Problem, and the Solution)
}

\section{Omer Wagner}

\begin{abstract}
Sea freight prices have risen sharply, due to the COVID-19 crisis, global shortages of ships, declining competition in the field, and containers of contagious demand. The increase in transportation costs leads to the increase in the value of goods for customs purposes, and to a further collection of customs duties. The Israeli law allows the state to facilitate importers and waive the extra customs duties, and similar and other facilitations have been made in the past. Therefore, all that is required is the flexibility and activation of goodwill on the part of the state, when interpreting the law.
\end{abstract}

Keywords: Customs, Valuation, Transport, Covid19, Israel.

\section{INTRODUCTION}

In the past year, sea freight prices have risen sharply, an increase that has not been remembered for many years.

Thus, according to various publications, about a year ago, renting a container for sea transportation from China to Israel, costed about 2,000\$, and today, the same transportation costs about $15,000 \$$.

According to the publications, the reasons for this significant increase are due, among other things, to the COVID-19 crisis, global shortages of ships, declining competition in the field, and containers of contagious demand. In addition, there is a "Made of Israel" reason, since due to the congestion at ports in Israel, there are ships that prefer not to dock in Israel, and then the number of ships that can dock in Israel is even smaller (1).

Apart from the increase in transportation costs, which is expected to lead to a wave of price increases in the sale of products in Israel, there is another parameter that is slightly pushed to the margins, and that is the increase in the value of goods for customs purposes, due to rising transportation prices. This increase in prices leads to further collection of customs duties, purchase tax and import taxes, due to the increase in value.

Manuscript received on July 17, 2021.

Revised Manuscript received on July 22, 2021.

Manuscript published on July 30, 2021.

* Correspondence Author

Omer Wagner*, LL.B (Bachelor of law), Advocate for customs and international trade, Department of Indirect Taxation, PWC Israel, Tel-Aviv Jaffa, Israel.

(C) The Authors. Published by Blue Eyes Intelligence Engineering and Sciences Publication (BEIESP). This is an open access article under the CC BY-NC-ND license (http://creativecommons.org/licenses/by-nc-nd/4.0/)

As I will present in this review, in my opinion - the Israeli already allows the state to facilitate importers at this oint - and similar and other facilitations have been made in the past. All that is required is the flexibility and activation of goodwill on the part of the state, when interpreting the law.

\section{DISCUSSION}

How is the value of the goods determined for customs purposes in the State of Israel?

The Israeli law (2) stipulates that the value of the

"The price paid or to be paid for the goods, when sold for export to Israel ... plus the expenses and amounts specified in section 133."...

The relevant Section which refers to "assists" to the transaction price for customs purposes (3), enumerates a large number of examples, one of which, relevant to its case, relates to transportation costs, and subscribes (4), which

"The following costs involved in bringing the goods to the port of import or place of import - (a) The cost of transporting the goods to the port of import or place of import, excluding such costs incurred due to special circumstances beyond the control of the importer and the Director determining not to include them in the transaction; This includes types of goods, types of And-

- "The cost of insurance."(5)

That is, if we try to compare this to the terms of sale of Incoterms (6), it seems that the State of Israel has determined that the customs duty will be levied on the value of CIF (cost, insurance \& freight), i.e. the value of the goods including transport and insurance.

How is the value determined for customs, worldwide? Is it FOB or CIF? 
It should be noted that there is no uniform rule in this matter.

Most countries in the world are members of the World Trade Organization (WTO) and the World Customs Organization (WCO), and by virtue of their membership, have signed an international agreement on the valuation of goods for customs purposes (7).

The agreement sets out a number of rules regarding the way goods are valued for customs purposes, but it does not stipulate any binding rules regarding transportation.

GATT Valuation agreement, stipulates as follows (8):

"In framing its legislation, each Member shall provide for the inclusion in or the exclusion from the customs value, in whole or in part, of the following: (a) the cost of transport of the imported goods to the port or place of importation;

(b)loading, unloading and handling charges associated with the transport of the imported goods to the port or place of importation; and

(c) the cost of insurance."

There are countries where the value on which the customs duty is imposed is FOB (free on board), that is, without the international transport cost - Such as the United Stated, Australia, New-Zealand, as will be discussed below.

But, the majority of countries have chosen to impose customs duties on CIF value of the goods, including the international transport cost - such as Israel, Singapore (9), and many more, as is clearly indicated by the WCO review from 2018 (10):

"The majority of WTO Members made the one-off decision to include these elements in the Customs value; known as CIF (cost, insurance, freight) basis. include these elements is known as FOB (free on board)."

Customs valuation in the United States

The United States have chosen a different method than in the State of Israel, and in the United States, customs duties are imposed on the value without international transportation cost.

Thus, the corresponding section in American law to the Israeli Customs Ordinance, which deals with the "transaction price", states in US law that (11):

"The transaction value of imported merchandise is the price actually paid or payable for the merchandise when sold for exportation to the United States "..

As for transportation costs, American law goes on to declare that the value to customs will not include them (12):

"The transaction value of imported merchandise does not include any of the following, if identified separately from the price actually paid or payable and from any cost or other item referred to in paragraph (1): (A) Any reasonable cost or charge that is incurred for-

(ii) the transportation of the merchandise after such importation". The system used by the few Members who chose not to

\section{Customs valuation in Australia}

The Australian legislator has chosen to impose customs duties on the FOB value, similarly to the United states. The Australian relevant law, rules (13):

"Unless the contrary intention appears in this Act or in another Act, the value of imported goods for the purposes of an Act imposing duty is their customs value and the Collector shall determine that customs value in accordance with this section".

The law defines the customs value as the transaction value (14):

"Where a Collector can determine the transaction value of imported goods, their customs value is their transaction value."

The law continues and rules that the transaction value should be adjusted, as follows (15):

"The transaction value of imported goods is an amount equal to the sum of their adjusted price in their import sales transaction and of their price related costs to the extent that those costs have not been taken into account in determining the price of the goods."

Afterwards, the law defines the price related costs which should be added to the transaction value (16):

(c) foreign inland freight and foreign inland insurance in relation to the goods paid or payable, directly or indirectly, by or on behalf of the purchaser;

Therefore, since the Australian Law rules that only inland freight and insurance should be added to the customs value, marine or aerial transportation costs, are excluded from the customs value.

This point is well explained in the Australian customs valuation guide, as follows (17):

"Note that the above provisions are aimed at assessing the total amount paid for the goods, packed and in export condition, at their place of export.

CIF ("cost, insurance, freight") contracts will require adjustments in respect of: (1) overseas inland freight and insurance after the place of export; (2) overseas freight and shipping charges; and (3) other charges imposed after the place of export."

Customs Valuation in New Zealand

The New Zealand relevant law, defines the customs valuation method, as follows (18):

"The primary basis for determining the Customs value of imported goods is the transaction value of the goods".

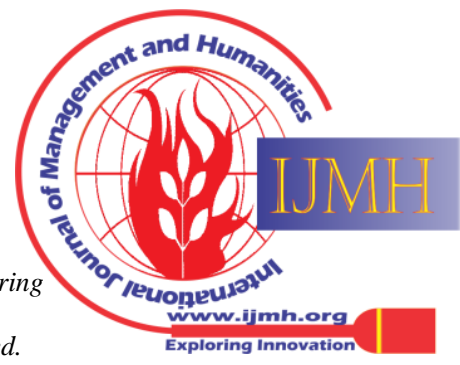


The Law continues and notes that several adjustments should be made to the customs value (19):

"The transaction value of imported goods is to be calculated by-

(a)taking the price paid or payable for the goods when sold for export to New Zealand; and

(b)on the basis of sufficient information, adding amounts (to the extent that each amount is not included in the price paid or payable for the goods when sold for export to New Zealand) equal to the following: (vii) the costs of transportation and insurance of, and the loading, unloading, and handling charges, and other charges and expenses associated with the transportation of, the imported goods until the goods have left the country of export if those costs, charges, and expenses are paid or payable by the buyer, directly or indirectly, to or for the benefit of the seller as a condition of the transaction;"

The New Zealand Law does not stop right here, but also defines the exclusions, the deductions which should be made to the customs value (20):

(c) on the basis of sufficient information, deducting amounts (to the extent that each amount is included in the price paid or payable for the goods when sold for export to New Zealand) equal to the following:

(i) the costs of transportation and insurance of, and the loading, unloading, and handling charges, and other charges and expenses associated with the transportation of, the imported goods from the time the goods have left the country of export, other than any cost, charge, or expense referred to in subparagraph (ii)(B):

Therefore, is seems that the customs valuation method of New-Zealand is similar to the United states and Australia.

Customs Valuation comparison- Summary

Hence, it seems that in the US, Australia and New Zealand, since the customs valuation method is based on the FOB value, an increase in international freight rates, does not increase the value of the goods for customs purposes.

In Israel, Singapore and most of the States, on the other hand, any increase in international freight also embodies the increase in value to customs, and, accordingly, increases the customs burden imposed on the importer.

That is, if we assume for the purpose of the example, that a spare part for a car is subject to a purchase tax of about $20 \%$ of the value to customs, then any increase of $1,000 \$$ in transportation prices embodies an additional purchase tax of $200 \$$, collected by the State of Israel.

Since this is an indirect tax, it will, by its very nature, ultimately be passed on to the entire public, in the form of rising prices.

How has the State of Israel dealt with such similar situations in the past? by a wide variety of reasons. Among other things, wars,
Price increases in the field of transportation can be caused

closures, sanctions, strikes, and a host of other reasons may increase transportation prices.

In this regard, the Israeli law stipulates that in exceptional situations, the director of customs may not include in the value of customs certain transportation costs. The law calls them (21):

"such costs incurred due to special circumstances over which the importer has no control and the manager has determined that they should not be included in the value of the transaction;"

These are, in fact, transportation costs that are a kind of "force majeure" that the importer did not have the ability to prevent.

It should be noted that the Customs Authority exercised this authority, and sometimes exempted transport costs, due to certain circumstances.

On April 24 ${ }^{\text {th }}$, 2006, Customs ruled that transportation costs due to the Second Lebanon War would not be included in the customs entry:

"In accordance with my authority under section 133 (a) (5) (a) of the Customs Ordinance, I stipulate that war levies and additional transportation costs incurred by importers due to the security incidents in the north of the country, should not be included in the value of the transaction for the purpose of calculating the import taxes. It is clarified that these are additional transportation, unloading and loading costs listed in the cargo account that were caused due to the security incidents".

On June $6^{\text {th }}, 2008$, the Customs ruled that the container demurrage fee beyond the agreed, will not be included in the customs entry:

"The demurrage fee in the importing country, which is charged for the use of the container beyond the agreed period between the ship's agent and the importer, will not be included for import taxes".

On September $7^{\text {th }}$, 2008, Customs exempted certain transportation costs in respect of strikes from being included in the customs entry, stating:

"In accordance with my authority under section 133 (a) (5) (a) of the Customs Ordinance, I provide that additional transportation costs incurred by importers

due to sanctions in the ports of Israel, will not be considered for the transaction value for the purpose of calculating import taxes. It is clarified that these are additional transportation, unloading and loading costs listed in the cargo account, which were caused due to the sanctions and the importer has no control over them. The importer must prove the existence of such additional costs".

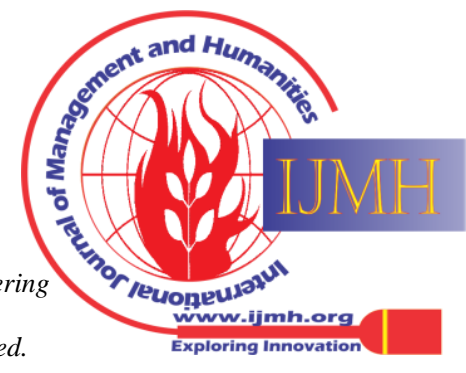




\section{CONCLUSION}

Can the state of Israel relieve importers in the current situation?

According to the publications, the Israeli Chamber of Commerce recently appealed to the director of customs to exercise his authority, and set a type of ceiling on which customs would be imposed, even if in practice transport costs are currently more expensive, and this application was denied by customs (22).

Customs stated that this was a request to reduce the actual cost of transport - something that is not possible, noting that when it came to a request to reduce additions to the value of transport, such as vessels that declared "end of journey" in Cyprus and refrained from entering Israel due to the COVID-19 crisis. Customs further stated that it has not been proven that the increase in transportation prices is due to the COVID-19 or an unforeseen situation, therefore no reduction can be made under the exception in section 133 (a)(5) of the Customs Ordinance, and even claimed that if the State of Israel accepts the claim, this will be a breach of the International Agreement on the Valuation of Good.

So the question is basically: can in the present case, transportation costs raised by tens or hundreds of percent, due to global COVID-19 crisis, shortage of ships, heavy loads in Israeli ports, shortage of containers, constitute "special circumstances beyond the importer's control"?

With all due respect, in my opinion, this point deserves further thought and discussion.

In my opinion, if the Second Lebanon War is an unforeseen event over which the importer has no control, as well as sanctions or strikes, then the interpretation of the law could be a little more flexible, and determined that a global COVID-19 crisis, shortage of ships, containers, To be considered as special circumstances over which the importer has no control.

In this regard, I would like to bring to the readers' attention a ruling given in the Israeli court on another issue, but it was stated in it, in relation to the Corona crisis, that it is certainly an unexpected event (23):

'It is hard to believe that the reasonable person could or should have expected the full far- reaching consequences of the Corona epidemic, including on the economy and commercial life, in Israel and around the world. We are dealing with an unparalleled epidemic which has no precedent in the last hundred years (at least since the Spanish Flu epidemic which caused many deaths around the world between the years 1918 - 1920)".

These right things, can and should be applied, in my opinion - also in the field of international trade and customs valuation.

Does anyone in the Customs Authority believe that the simple, lone importer, even if it is a wealthy business company, has any control over the changes in world freight rates? Could any importer have anticipated the corona crisis?

In the end, if my opinion will be adopted, the legal solution, is to relieve the importers of the customs duty imposed on the transport that has become more expensive - it already exists. The "invention of the wheel" is not required here.

Now only goodwill is required, and little flexibility in interpreting the law.

\section{REFERENCES}

1. https://www.ynet.co.il/economy/article/rJrNcwAcd

2. Section 132 (a) of the Israeli Customs Ordinance [new version]

3. Section 133 of the Israeli Customs Ordinance [new version]

4. Section 133 (a)(5)(a) of the Israeli Customs Ordinance [new version]

5. Subsection 133 (a)(5)(c) of the Israeli Customs Ordinance [new version]

6. https://iccwbo.org/resources-for-business/incoterms-rules/incoterms2020/

7. Customs Valuation Agreement (Implementation of Article VII of the GATT) -

https://www.wto.org/english/res_e/publications_e/ai17_e/cusval_e.ht m

8. Section 8.2 of the Customs Valuation Agreement

9. https://www.customs.gov.sg/businesses/valuation-duties-taxes-fees/e stablishing-customs-value-for-imports

10. World Customs Organization (WCO) Guide to Customs Valuation and Transfer Pricing, New Edition, 2018-

http://www.wcoomd.org/-/media/wco/public/global/pdf/topics/key-is sues/revenue-package/wco-guide-to-customs-valuation-and-transferpricing.pdf?la=en

11. United states Tariff act of 1930, 19. U.S.C. $\$ 1401 \mathrm{a}(\mathrm{b})(1)$ https://uscode.house.gov/view.xhtml?path=/prelim@title19/chapter4 \&edition=prelim

12. United states Tariff act of 1930,19 . U.S.C. $\$ 1401 \mathrm{a}(\mathrm{b})(3)$

13. Australian Customs Act of 1901, section 159(1) https://www.legislation.gov.au/Details/C2020C00272

14. Australian Customs Act of 1901, Section 159(2)

15. Australian Customs Act of 1901, Section 161(1)

16. Australian Customs Act of 1901, Section 154

17. Australian Government, Department of Immigration and Border Protection- Instructions and Guidelines- Customs Valuation, September

2011-

https:/www.abf.gov.au/help-and-support-subsite/files/instructions-g uidelines-customs-valuation.pdf

18. Schedule 4 of the New Zealand Customs and Excise act of 2018, Part 1 , method 1 , section $4(1)$.

https://www.legislation.govt.nz/act/public/2018/0004/latest/DLM704 0110.html?search=qs_act\%40bill\%40regulation\%40deemedreg_Cus toms+and+Excise+Act+2018_resel_25_h\&p=1

19. Schedule 4 of the New Zealand Customs and Excise act of 2018, Part 1 , method 1 , section 7

20. Schedule 4 of the New Zealand Customs and Excise act of 2018, Part 1 , method 1 , section 7(c)

See also the NZ customs valuation guide from 2018https:/www.customs.govt.nz/globalassets/documents/guides/guide-a pply-customs-valuation-ruling-on-imported-goods.pdf

21. Section 133 (a)(5) of the Israeli Customs Ordinance

22. https://www.chamber.org.il/foreigntrade/1109/1111/116962

23. Israeli judgement: Hdlt (Tel-Aviv) 26076-02-20 Adv. Israel Bachar vs. comfortability systems (2007) Ltd. (July 8th, 2020)

\section{AUTHORS PROFILE}

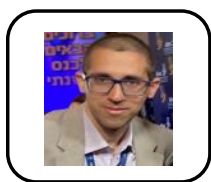

Omer Wagner, Adv. LL.B in Law, Bar Ilan University, Ramat Gan, Israel. Specializes in customs duty, indirect taxation, import, export, international trade, trade levies, regulation. Currently employed at PWC Israel, indirect taxation department. 